Article

\title{
Cryptosporidium Species and C. paroum Subtypes in Farmed Bamboo Rats
}

\author{
Falei Li ${ }^{1,2}$, Wentao Zhao ${ }^{1}$, Chenyuan Zhang ${ }^{1}$, Yaqiong Guo ${ }^{1}$, Na Li ${ }^{1}$, Lihua Xiao ${ }^{1,2, *(D)}$ \\ and Yaoyu Feng 1,2,*iD \\ 1 Center for Emerging and Zoonotic Diseases, South China Agricultural University, Wushan Road, \\ Guangzhou 510642, China; falei0316@126.com (F.L.); 17818522213@163.com (W.Z.); \\ chenyuanzhang@gdaib.edu.cn (C.Z.); guoyq@scau.edu.cn (Y.G.); nli@scau.edu.cn (N.L.) \\ 2 Guangdong Laboratory for Lingnan Modern Agriculture, Wushan Road, Guangzhou 510642, China \\ * Correspondence: 1xiao@scau.edu.cn (L.X.); yyfeng@scau.edu.cn (Y.F.)
}

Received: 6 November 2020; Accepted: 1 December 2020; Published: 2 December 2020

\begin{abstract}
Bamboo rats (Rhizomys sinensis) are widely farmed in Guangdong, China, but the distribution and public health potential of Cryptosporidium spp. in them are unclear. In this study, 724 fecal specimens were collected from bamboo rats in Guangdong Province and analyzed for Cryptosporidium spp. using PCR and sequence analyses of the small subunit rRNA gene. The overall detection rate of Cryptosporidium spp. was $12.2 \%$ (88/724). By age, the detection rate in animals under 2 months $(23.2 \%$ or $13 / 56)$ was significantly higher than in animals over 2 months $\left(11.2 \%\right.$ or $75 / 668 ; \chi^{2}=6.95$, $d f=1, p=0.0084)$. By reproduction status, the detection rate of Cryptosporidium spp. in nursing animals $(23.1 \%$ or $27 / 117)$ was significantly higher than in other reproduction statuses $(6.8 \%$ or $4 / 59$; $\left.\chi^{2}=7.18, d f=1, p=0.0074\right)$. Five Cryptosporidium species and genotypes were detected, including Cryptosporidium bamboo rat genotype I $(n=49)$, C. parvum $(n=31)$, Cryptosporidium bamboo rat genotype III $(n=5)$, C. occultus $(n=2)$, and C. muris $(n=1)$. The average numbers of oocysts per gram of feces for these Cryptosporidium spp. were 14,074, 494,636, 9239, 394, and 323, respectively. The genetic uniqueness of bamboo rat genotypes I and III was confirmed by sequence analyses of the $70 \mathrm{kDa}$ heat shock protein and actin genes. Subtyping C. parvum by sequence analysis of the $60 \mathrm{kDa}$ glycoprotein gene identified the presence of IIoA15G1 $(n=20)$ and IIpA6 $(n=2)$ subtypes. The results of this study indicated that Cryptosporidium spp. are common in bamboo rats in Guangdong, and some of the Cryptosporidium spp. in these animals are known human pathogens.
\end{abstract}

Keywords: Cryptosporidium parvum; subtype; bamboo rat; human pathogen

\section{Introduction}

Cryptosporidium spp. are major pathogens that mainly parasitize the gastrointestinal epithelium, causing moderate-to-severe diarrhea in humans and animals [1,2]. They are responsible for significant mortality in both young children [1,3] and neonatal farm animals [4-8]. In addition, cryptosporidiosis has been associated with retarded growth in humans and farm animals [9-12].

Cryptosporidium spp. are especially common in rodents [13]. Among the $>40$ established Cryptosporidium species and an equal number of genotypes of unknown species status [14], C. parvum is commonly found in various rodents in China [15]. Other Cryptosporidium spp. from rodents have more limited host ranges, such as C. meleagridis and Cryptosporidium deer mouse genotypes I, II, III, and IV in deer mice [16-19]; Cryptosporidium chipmunk genotypes I and II in chipmunks [16]; and Cryptosporidium ferret genotype, C. rubeyi and several squirrel genotypes in squirrels [20-23].

Bamboo rats are widely farmed in southern China. They are commonly infected with Cryptosporidium spp. Several Cryptosporidium species and genotypes have been identified in these 
animals, including C. parvum, C. parvum-like genotype, C. occultus, and Cryptosporidium bamboo rat genotypes I and II [24,25]. Thus, the distribution of Cryptosporidium spp. in bamboo rats appears to be different from other rodents. At the subtype level, C. parvum subtypes found in bamboo rats also differ from those in other rodents. In China, rodents such as hamsters, chipmunks, and rats are mostly infected with the IId subtype family of C. parvum, with IIdA15G1 and IIdA19G1 as the most common subtypes [26]. In contrast, bamboo rats in southern China are seemingly infected with rare IIo and IIp subtype families of $C$. parvum $[25,27]$. Most of data on these two $C$. parvum subtype families in bamboo rats, however, were from a study of animals in Jiangxi, Guangxi, and Hainan [24].

In this study, we examined the occurrence of Cryptosporidium spp. and C. parvum subtypes in bamboo rats in Guangdong Province. The distributions of Cryptosporidium spp. and C. parvum subtypes were compared among farms, age groups and reproduction statuses. The oocyst shedding intensity was compared among Cryptosporidium species and genotypes for the first time.

\section{Results}

\subsection{Occurrence of Cryptosporidium spp. in Bamboo Rats}

The overall detection rate of Cryptosporidium spp. in bamboo rats in Guangdong was $12.2 \%$ (88/724). The detection rate of Cryptosporidium spp. on farm 1 (35.9\% or 33/92) was significantly higher than on farm $2\left(3.5 \%\right.$ or $5 / 142 ; \chi^{2}=42.95, d f=1, p<0.0001 ; d f$ : degrees of freedom), farm 3 $\left(1.0 \%\right.$ or $\left.2 / 205 ; \chi^{2}=74.38, d f=1, p<0.0001\right)$, farm $5\left(0 \%\right.$ or $\left.0 / 56 ; \chi^{2}=25.85, d f=1, p<0.0001\right)$, and farm $6\left(19.7 \%\right.$ or $\left.37 / 188 ; \chi^{2}=8.63, d f=1, p=0.0033\right)$. The difference in detection rate between farms 4 ( $26.8 \%$ or $11 / 41)$ and 1 was not significant $\left(\chi^{2}=1.05, d f=1, p=0.3062\right.$; Table 1$)$.

By age, the detection rates of Cryptosporidium spp. in bamboo rats ranged from $0.0 \%(0 / 8)$ in animals of 6-8 months to $23.2 \%(13 / 56)$ in animals under 2 months. The detection rate of Cryptosporidium spp. in animals under 2 months of age was significantly higher than in older animals (11.2\% or 75/668; $\chi^{2}=6.95, d f=1, P=0.0084$; Table 2). By reproduction status of adult animals (1-3 years in age), nursing animals had a significantly higher detection rate $(23.1 \%$ or $27 / 117)$ than breeding animals $(4.9 \%$ or $\left.10 / 205 ; \chi^{2}=24.26, d f=1, p<0.0001\right)$, pregnant animals $\left(6.8 \%\right.$ or $\left.4 / 59 ; \chi^{2}=7.18, d f=1, p=0.0074\right)$, and nonpregnant animals $\left(10.6 \%\right.$ or $21 / 198 ; \chi^{2}=8.86, d f=1, p=0.0029$; Table 3$)$. 
Table 1. Occurrence of Cryptosporidium spp. and C. parvum subtypes in bamboo rats in Guangdong, China.

\begin{tabular}{|c|c|c|c|c|c|c|c|c|c|}
\hline \multirow[b]{2}{*}{ Farm } & \multirow[b]{2}{*}{ Age Group } & \multirow{2}{*}{$\begin{array}{c}\text { No. } \\
\text { Specimens }\end{array}$} & \multirow{2}{*}{$\begin{array}{c}\text { No. } \\
\text { Positive (\%) }\end{array}$} & \multicolumn{5}{|c|}{ Cryptosporidium spp. } & \multirow[b]{2}{*}{ C. paroum Subtype } \\
\hline & & & & $\begin{array}{l}\text { Bamboo Rat } \\
\text { Genotype I }\end{array}$ & $\begin{array}{l}\text { Bamboo Rat } \\
\text { Genotype III }\end{array}$ & C. occultus & C. muris & C. parvum & \\
\hline \multirow{3}{*}{1} & $<2$ months & 9 & $6(66.7)$ & 6 & - & - & - & - & - \\
\hline & $1-3$ years & 83 & $27(32.5)$ & 27 & - & - & - & - & - \\
\hline & subtotal & 92 & $33(35.9)$ & 33 & - & - & - & - & - \\
\hline \multirow{3}{*}{2} & $4-6$ months & 1 & $0(0.0)$ & - & - & - & - & - & - \\
\hline & 1-3 years & 141 & $5(3.5)$ & 4 & - & 1 & - & - & - \\
\hline & subtotal & 142 & $5(3.5)$ & 4 & - & 1 & - & - & - \\
\hline \multirow{6}{*}{3} & $<2$ months & 36 & $0(0.0)$ & - & - & - & - & - & - \\
\hline & $2-4$ months & 29 & $0(0.0)$ & - & - & - & - & - & - \\
\hline & $4-6$ months & 18 & $1(5.6)$ & - & - & 1 & - & - & - \\
\hline & 6-8 months & 8 & $0(0.0)$ & - & - & - & - & - & - \\
\hline & $1-3$ years & 114 & $1(0.9)$ & - & - & - & - & 1 & - \\
\hline & subtotal & 205 & $2(1.0)$ & - & - & 1 & - & 1 & - \\
\hline \multirow{3}{*}{4} & $2-4$ months & 16 & $6(37.5)$ & 3 & - & - & - & 3 & IIoA15G1 (1) \\
\hline & $1-3$ years & 25 & $5(20.0)$ & 5 & - & - & - & - & - \\
\hline & subtotal & 41 & $11(26.8)$ & 8 & - & - & - & 3 & IIoA15G1 (1) \\
\hline \multirow{2}{*}{5} & $1-3$ years & 56 & $0(0.0)$ & - & - & - & - & - & - \\
\hline & subtotal & 56 & $0(0.0)$ & - & - & - & - & - & - \\
\hline \multirow{5}{*}{6} & $<2$ months & 11 & $7(63.6)$ & - & - & - & - & 7 & IIoA15G1 (5) \\
\hline & $2-4$ months & 17 & $6(35.3)$ & 3 & 1 & - & - & 2 & $\operatorname{IIoA15G1~(1)~}$ \\
\hline & 1-3 years & 160 & $24(15.0)$ & 1 & 4 & - & 1 & 18 & IIoA15G1 (13), IIpA6 (2) \\
\hline & subtotal & 188 & 37 (19.7) & 4 & 5 & - & 1 & 27 & IIoA15G1 (19), IIpA6 (2) \\
\hline & Total & 724 & $88(12.2)$ & 49 & 5 & 2 & 1 & 31 & IIoA15G1 (20), IIpA6 (2) \\
\hline
\end{tabular}


Table 2. Occurrence of Cryptosporidium spp. in farmed bamboo rats in Guangdong by age.

\begin{tabular}{|c|c|c|c|c|c|c|c|c|}
\hline \multirow[b]{2}{*}{ Age } & \multirow[b]{2}{*}{ No. Specimens } & \multirow[b]{2}{*}{ No. Positive (\%) } & \multicolumn{5}{|c|}{ Cryptosporidium spp. } & \multirow[b]{2}{*}{ C. parvum Subtype } \\
\hline & & & $\begin{array}{c}\text { Bamboo Rat } \\
\text { Genotype I }\end{array}$ & $\begin{array}{l}\text { Bamboo Rat } \\
\text { Genotype III }\end{array}$ & C. muris & C. occultus & C. paroum & \\
\hline$<2$ months & 56 & $13(23.2)$ & 6 & - & - & - & 7 & IIoA15G1 (5) \\
\hline 2-4 months & 62 & $12(19.4)$ & 6 & 1 & - & - & 5 & IIoA15G1 (2) \\
\hline 4-6 months & 19 & $1(5.3)$ & - & - & - & 1 & - & - \\
\hline 6-8 months & 8 & $0(0.0)$ & - & - & - & - & - & - \\
\hline $1-3$ years & 579 & $62(10.7)$ & 37 & 4 & 1 & 1 & 19 & IIoA15G1 (13), IIpA6 (2) \\
\hline Total & 724 & $88(12.2)$ & 49 & 5 & 1 & 2 & 31 & IIoA15G1 (20), IIpA6 (2) \\
\hline
\end{tabular}

Table 3. Occurrence of Cryptosporidium spp. in farmed adult bamboo rats in Guangdong by reproduction status.

\begin{tabular}{|c|c|c|c|c|c|c|c|c|}
\hline \multirow[b]{2}{*}{ Animal Status } & \multirow[b]{2}{*}{ No. Specimens } & \multirow[b]{2}{*}{ No. Positive (\%) } & \multicolumn{5}{|c|}{ Cryptosporidium spp. } & \multirow[b]{2}{*}{ C. paroum Subtype } \\
\hline & & & $\begin{array}{c}\text { Bamboo Rat } \\
\text { Genotype I }\end{array}$ & $\begin{array}{l}\text { Bamboo Rat } \\
\text { Genotype III }\end{array}$ & C. muris & C. occultus & C. paroum & \\
\hline Nursing & 117 & $27(23.1)$ & 5 & 3 & 1 & - & 18 & IIoA15G1(13), IIpA6 (2) \\
\hline Breeding & 205 & $10(4.9)$ & 8 & 1 & - & - & 1 & - \\
\hline Pregnancy & 59 & $4(6.8)$ & 4 & - & - & - & - & - \\
\hline Nonpregnant & 198 & $21(10.6)$ & 20 & - & - & 1 & - & - \\
\hline Total & 579 & $62(10.7)$ & 37 & 4 & 1 & 1 & 19 & IIoA15G1 (13), IIpA6 (2) \\
\hline
\end{tabular}




\subsection{Cryptosporidium Species and Genotypes Identified}

All 88 Cryptosporidium-positive specimens were successfully genotyped by sequence analysis of the SSU rRNA gene. Among them, five Cryptosporidium species and genotypes were detected, including bamboo rat genotype I in 49 specimens, C. parvum in 31 specimens, bamboo rat genotype III in 5 specimens, C. occultus in 2 specimens, and C. muris in 1 specimen. The SSU rRNA sequences from bamboo rat genotype I, bamboo rat genotype III, C. parvum, and C. occultus were identical to reference sequences MK956935 (from bamboo rats in China), MK956936 (from bamboo rats in China), MK956932 (from bamboo rats in China), and MK982467 (from calves in Bangladesh), respectively. The bamboo rat genotype III was previously named the C. parvum-like genotype. In contrast, the sequence from C. muris was similar to the reference sequence GU319781 from nonhuman primates in China, with three nucleotide substitutions. In phylogenetic analysis of the SSU rRNA sequences, these Cryptosporidium species and genotypes from bamboo rats clustered with their reference sequences (Figure 1a).

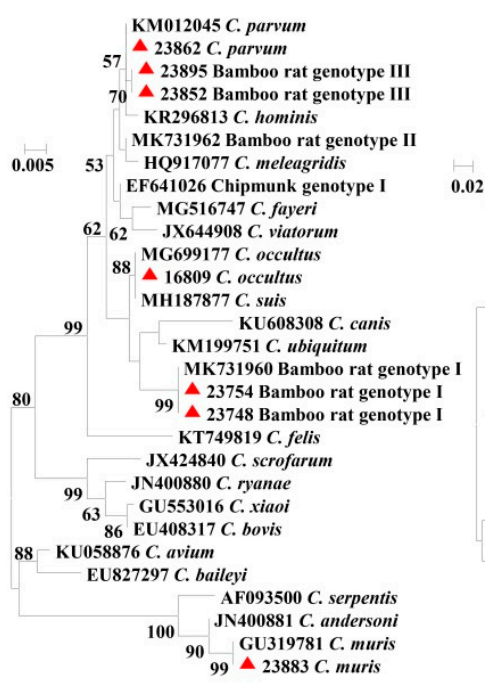

(a)

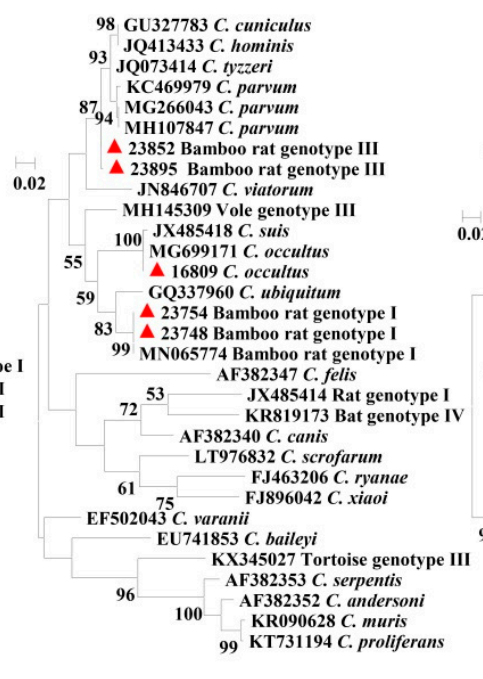

(b)

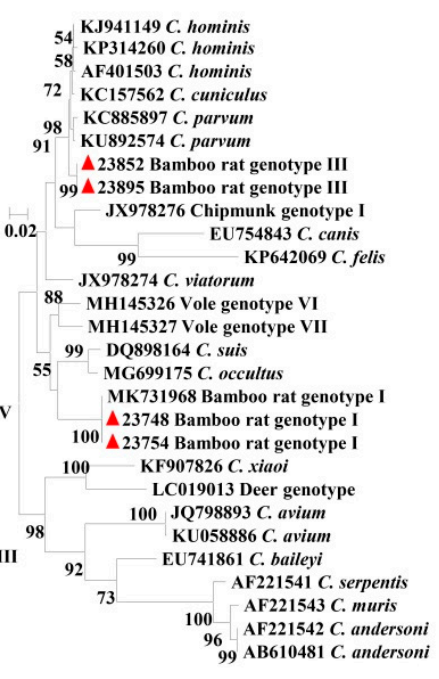

(c)

Figure 1. Phylogenetic relationship of Cryptosporidium spp. based on the maximum likelihood analyses of the SSU rRNA gene (a); actin gene (b) and $70 \mathrm{kDa}$ heat shock protein gene (c). Bootstrap values greater than $50 \%$ from 1000 replicates are displayed. The red triangles indicate the Cryptosporidium spp. identified in the present study.

Representative isolates of bamboo rat genotypes I and III and C. occultus were characterized by sequence analysis of the actin gene. The sequences from bamboo rat genotype I and C. occultus were identical to reference sequences MN065774 (from bamboo rats in China) and MG699171 (from Meriones unguiculatus in Czech Republic), respectively. The sequence from bamboo rat genotype III, however, was similar to the C. parvum sequence MG266043 from Apodemus agrarius in Slovakia, with 16 nucleotide substitutions. As expected, these Cryptosporidium species and genotypes clustered with their reference sequences in phylogenetic analysis of the actin gene (Figure 1b).

Nucleotide sequences of the $h s p 70$ gene were also obtained from representative isolates of bamboo rat genotypes I and III; the two C. occultus isolates were PCR-negative at this locus. The sequences from bamboo rat genotype I was identical to reference sequences MK731968 from bamboo rats in China. In contrast, the sequences from bamboo rat genotype III had 14 single nucleotide polymorphisms (SNPs) and 1 nucleotide deletion compared with C. parvum sequences (AF401503 and KU892574). As expected, bamboo rat genotypes I and III clustered these reference sequences in phylogenetic analysis of the $h s p 70$ gene (Figure 1c). 


\subsection{Age Pattern of Cryptosporidium Species and Genotypes}

Bamboo rat genotype I and C. parvum were the dominant Cryptosporidium spp. in bamboo rats, especially in animals under 2 months of age and in nursing adults. Among adult animals, both Cryptosporidium spp. were detected in nursing animals and breeding animals. In contrast, only bamboo rat genotype I was detected in pregnant and nonpregnant animals (Table 3 ). Among young animals, both bamboo rat genotype I and C. parvum were detected in animals under 4 months of age. They, however, were not detected in animals with an age of 4-8 months (Table 2).

\subsection{Occurrence of C. paroum Subtypes}

Twenty-two of the 31 C. parvum-positive specimens were successfully subtyped based on sequence analysis of the gp60 gene. Subtypes IIoA15G1 $(n=20)$ and IIpA6 $(n=2)$ were identified from them. The sequences generated were identical to reference sequences MK956002 and MK955996, respectively.

\subsection{Intensity of Oocyst Shedding among Cryptosporidium spp.}

The oocyst shedding intensity, oocysts per gram of feces (OPG), in Cryptosporidium-infected bamboo rats was measured using qPCR. The average OPG values were 494,636 $\pm 1,892,289$ for C. parvum ( $n=28), 9239 \pm 12,939$ for bamboo rat genotype III $(n=5), 14,074 \pm 46,621$ for bamboo rat genotype I $(n=39), 394 \pm 442$ for C. occultus $(n=3)$, and 323 for C. muris $(n=1$; Figure 2$)$.

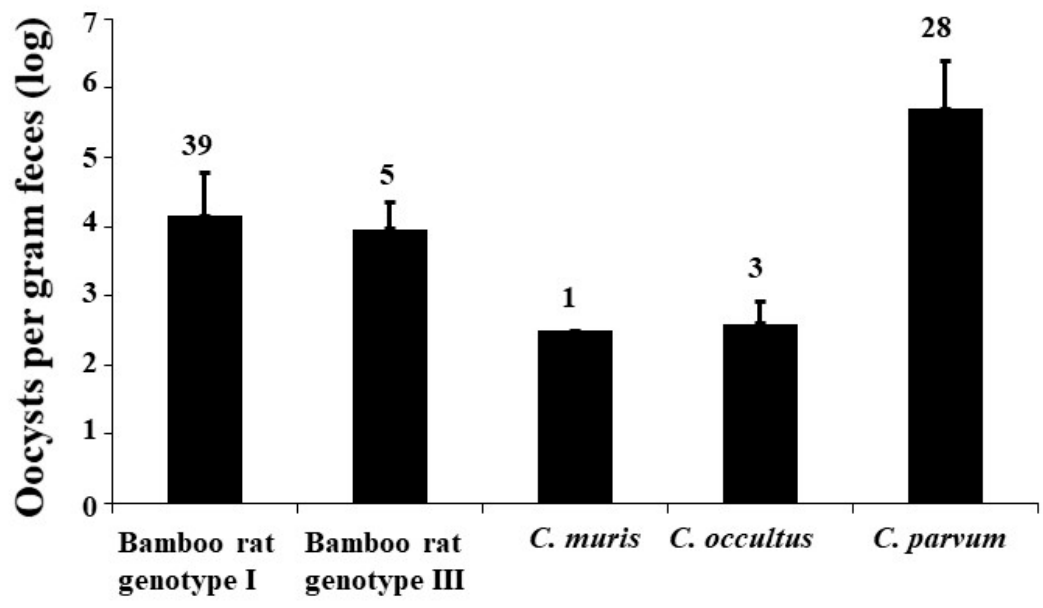

Figure 2. Oocyst shedding intensity (oocysts per gram of feces) of Cryptosporidium species and genotypes in bamboo rats (mean \pm standard deviation).

\section{Discussion}

The results of this study suggest that Cryptosporidium spp. are common in bamboo rats in Guangdong, China. The detection rate of Cryptosporidium spp. in present study (12.2\% or 88/724) is higher than in previous study $(2.2 \%$ or $1 / 46)$ in the same area [25]. It is also higher than the $3.2 \%$ detection rate in bamboo rats from a pet market [27]. In contrast, it is lower than several reports of Cryptosporidium spp. in farmed bamboo rats sampled in Guangxi (20.9\% or 100/477), Jiangxi (33.3\% or 51/153), and Hainan (69.6\% or 55/79) [24]. Among six farms, the detection rate of Cryptosporidium spp. on farm $1(35.9 \%)$ was higher than other farms $(0.0-26.8 \%)$, probably because of the higher animal density and poor hygiene conditions on the farm. The detection rates of Cryptosporidium spp. in animals under 2 months of age (23.2\%) and nursing animals $(23.1 \%)$ were higher than other age groups (0.0-19.4\%) and reproduction statuses (4.9-10.6\%). These differences might be due to the lower immunity of young animals and nursing animals, making them more susceptible to infection with Cryptosporidium spp. As the detection rates differed among age groups and reproduction statuses, these variations in detection rates among studies are expected. 
Diverse Cryptosporidium species and genotypes are present in farmed bamboo rats in the study area. Five Cryptosporidium species and genotypes were identified in this study, including bamboo rat genotype I (55.7\%, 49/88), C. parvum (35.2\%, 31/88), bamboo rat genotype III $(5.7 \%, 5 / 88)$, C. occultus $(2.3 \%, 2 / 88)$, and C. muris $(1.1 \%, 1 / 88)$. Among them, bamboo rat genotype I and C. paroum are dominant Cryptosporidium spp. in present study. This is similar to observations of two previous studies [24,25]. However, bamboo rat genotype III, commonly found in bamboo rats in Guangxi and Hainan [24], is rare in the present study. Among the five Cryptosporidium species and genotypes identified in the study, C. parvum is a well-known human pathogen and has been found in a wide range of animals. Cryptosporidium muris and C. occultus, in contrast, are mostly Cryptosporidium species of rats and have been only occasionally found in humans [14]. Although bamboo rat genotypes I and III are genetically related to C. ubiquitum and C. parvum, respectively, in sequence analysis of three genetic loci, it is still unclear whether they can infect humans $[14,28]$.

Results of oocyst shedding intensity in this study suggest that bamboo rats could be natural hosts of bamboo rat genotype I, bamboo rat genotype III, and C. parvum. Among five Cryptosporidium spp. identified in this study, these three Cryptosporidium genotypes had higher oocyst shedding intensity than C. occultus and C. muris. In addition, numerous bamboo rats are known to be infected with bamboo rat genotypes I and III and C. parvum. In contrast, brown rats appear to be natural hosts of C. occultus and C. muris [29-31]. Infection with these two Cryptosporidium species in bamboo rats could be due to contact with Cryptosporidium-infected wild rats living in the same ecological niche.

The unique C. paroum subtypes identified in the study probably represent emerging pathogens in a broad range of hosts. Thus far, more than 20 C. parvum subtype families have been identified based on sequence analyses of the gp60 gene [32]. Among them, the IIo and IIp were previously seen in a few bamboo rats in Sichuan, China and were considered rare C. parvum subtype families [27]. IIo subtypes, however, have been found in numerous bamboo rats from Jiangxi, Guangxi, and Hainan in southern China [24]. One IIo subtype, IIoA14, has also been widely found in crab-eating macaques in Hainan, China [33]. Human infections with Ilo subtypes have been identified in Thailand and New Zealand [34-36]. IIp subtypes of C. parvum also appear to be common in bamboo rats, having been thus far found in Jiangxi, Sichuan, Guangxi, Guangdong, and Hainan [24,27]. As they are genetically related to IId and IIo subtypes, they could also have a broader host range and human-infective potential [33]. Interestingly, IIp subtypes were much more prevalent than IIo subtypes in the previous survey of Cryptosporidium spp. in bamboo rats in Jiangxi, Guangxi, and Hainan. In the present study in Guangdong, the IIoA15G1 subtype was more commonly detected than the IIpA6 subtype.

There appears to be some transmission of $C$. parvum between nursing bamboo rats and their babies. Most C. parvum infections in adult bamboo rats (18 of 19 C. parvum-positive) were detected in nursing mothers; only one of them was found in another adult bamboo rat. In contrast, all C. parvum infections in young bamboo rats ( 12 of 12 C. parvum-positive) were detected in animals under 4 months of age. The $C$. parvum infections in nursing animals were probably due to sharing cages between the nursing dams and their babies. This is supported by the result of subtype analysis, in which the IIoA15G1 subtype was commonly found in both nursing animals and young bamboo rats. This is also consistent with results of studies in sheep and cattle, in which C. parvum is mostly detected in pre-weaned animals [37-40]. As the number of animals examined in the present study is small, further studies are needed to support this hypothesis. In contrast, Cryptosporidium bamboo rat genotype I appeared to be transmitted differently from C. parvum, as it was commonly found in adult bamboo rats of all reproduction statuses.

\section{Materials and Methods}

\subsection{Ethics Statement}

All fecal specimens were collected from bamboo rats with the approval of the farmers. The animals were handled in compliance with the regulations of the Chinese Laboratory Animal Administration 
Act of 2017. The study protocol was approved by the Research Ethics Committee of the South China Agricultural University (approval no. 2019g001).

\subsection{Specimens}

A total of 724 fecal specimens were collected during March to May 2019 from bamboo rats on six farms in Guangdong Province, China. On these farms, animals were kept in cages of $60 \times 60 \times 60 \mathrm{~cm}$. Animals under six months of age were mostly kept in groups of 10, while older animals (between 7 months and 3 years) were kept in groups of 3 . For the former, four specimens were collected from fresh feces in different corners of the cage, while for the latter, only one fecal specimen was collected from the cage (Table 1). These fecal specimens were stored in $2.5 \%$ potassium dichromate at $4{ }^{\circ} \mathrm{C}$ before DNA extraction.

The bamboo rats examined were divided into five age groups, including $<2$ months, $2-4$ months, 4-6 months, 6-8 months, and 1-3 years (Table 2). The adult animals (1-3 years-old) were further divided into four reproduction statuses: nursing (female bamboo rats feeding babies), breeding (one female and 1-2 males kept together for mating), pregnancy, and nonpregnancy (Table 3). On the studies farms, pregnant bamboo rats were moved to new cages for delivery after for delivery after cleaning of the cages without any further disinfection.

\subsection{Detection, Genotyping and Subtyping of Cryptosporidium spp.}

Fecal specimens were washed off potassium dichromate with distilled water by centrifugation at $2000 \times g$ for $10 \mathrm{~min}$. Genomic DNA was extracted from $200 \mathrm{mg}$ washed fecal material using the Fast DNA Spin Kit for Soil (MP Biomedical, Santa Ana, CA, USA) as described [41]. Cryptosporidium spp. in the extracted DNA were detected using a nested PCR assay targeting a 830-bp fragment of the small subunit rRNA (SSU) rRNA gene [42]. The C. parvum identified was subtyped by sequence analysis of a $\sim 800$-bp fragment of the $60 \mathrm{kDa}(g p 60)$ gene [43]. Representative isolates of the bamboo rat genotypes I and III and C. occultus were further characterized by sequence analyses of the $70 \mathrm{kDa}$ heat shock protein ( $h s p 70)$ and actin genes $[44,45]$.

\subsection{Measurement of Oocyst Shedding Intensity}

The intensity of oocyst shedding in Cryptosporidium-positive specimens from naturally infected bamboo rats was measured by quantitative PCR (qPCR) targeting the SSU rRNA gene $[33,46]$. The qPCR was conducted on a LightCycler 480 II (Roche, Indianapolis, IN, USA). To calculate oocysts per gram of feces (OPG), Cq (quantitation cycle) values generated were analyzed based on a standard curve constructed with DNA preparations from fecal specimens spiked with known numbers of oocysts of the IOWA (USA) strain of C. parvum (Waterborne, Inc., New Orleans, LA, USA).

\subsection{Sequence Analysis}

All secondary PCR products from Cryptosporidium-positive specimens were sequenced bi-directionally on an ABI 3730 Autosequencer (Applied Biosystems, Foster City, CA, USA) for determining Cryptosporidium spp. and C. parvum subtypes. The nucleotide sequences generated were assembled using ChromasPro 2.1.5.0 (http://technelysium. com. au/ChromasPro. html), edited using BioEdit 7.1.3.0 (http://www.mbio.ncsu.edu/BioEdit/bioedit.html), and aligned with reference sequences downloaded from GenBank using ClustalX 2.0.11 (http://clustal.org). Phylogenetic analysis of sequence generated was performed by constructing maximum likelihood trees using Mega 6.0 (http://www.megasoftware.net/) based on substitution rates calculated using the general time reversible model. The robustness of clade formation was assessed using bootstrapping with 1000 replicates. Representative sequences generated in this study were submitted to the GenBank under accession numbers MW092529-MW092535 and MW117315-MW117325. 


\subsection{Statistical Analysis}

The occurrence rates of Cryptosporidium spp. in bamboo rats were compared among farms, age groups, and reproduction statuses using the chi-square test implemented in SPSS v.20.0 (IBM Corp., New York, NY, USA). Differences were considered significant at $p \leq 0.05$.

\section{Conclusions}

The results of this study suggest that divergent Cryptosporidium spp., including C. parvum, bamboo rat genotypes I and III, C. occultus and C. muris, occur in farmed bamboo rats in Guangdong, China. The C. parvum identified belongs to the unique subtype families IIo and IIp. As most of the Cryptosporidium species and C. parvum subtypes are not commonly found in domestic animals, they could have wildlife origin and have maintained at high transmission intensity in some of the semi-domesticated exotic animals. Attention should be paid to their spillover to other farm animals as well as human populations.

Author Contributions: Conceptualization, L.X. and Y.F.; data curation, F.L.; formal analysis, F.L.; funding acquisition, L.X. and Y.F.; investigation, W.Z. and C.Z.; methodology, L.X. and Y.F.; project administration, N.L.; resources, Y.F.; software, L.X. and Y.F.; supervision, Y.G.; validation, L.X. and Y.F.; visualization, L.X. and Y.F.; writing—original draft, F.L.; writing—review and editing, L.X. All authors have read and agreed to the published version of the manuscript.

Funding: This research was funded by the National Natural Science Foundation of China (U1901208 and 31820103014), 111 Project (D20008), and Innovation Team Project of Guangdong University (2019KCXTD001).

Conflicts of Interest: The authors declare no conflict of interest.

\section{References}

1. Kotloff, K.L.; Nataro, J.P.; Blackwelder, W.C.; Nasrin, D.; Farag, T.H.; Panchalingam, S.; Wu, Y.; Sow, S.O.; Sur, D.; Breiman, R.F.; et al. Burden and aetiology of diarrhoeal disease in infants and young children in developing countries (the Global Enteric Multicenter Study, GEMS): A prospective, case-control study. Lancet 2013, 382, 209-222. [CrossRef]

2. Meganck, V.; Hoflack, G.; Opsomer, G. Advances in prevention and therapy of neonatal dairy calf diarrhoea: A systematical review with emphasis on colostrum management and fluid therapy. Acta Vet. Scand. 2014, 56, 75. [CrossRef]

3. Sow, S.O.; Muhsen, K.; Nasrin, D.; Blackwelder, W.C.; Wu, Y.; Farag, T.H.; Panchalingam, S.; Sur, D.; Zaidi, A.K.; Faruque, A.S.; et al. The Burden of Cryptosporidium Diarrheal Disease among Children $<24$ Months of Age in Moderate/High Mortality Regions of Sub-Saharan Africa and South Asia, Utilizing Data from the Global Enteric Multicenter Study (GEMS). PLoS Negl. Trop. Dis. 2016, 10, e0004729. [CrossRef]

4. Izzo, M.M.; Kirkland, P.D.; Mohler, V.L.; Perkins, N.R.; Gunn, A.A.; House, J.K. Prevalence of major enteric pathogens in Australian dairy calves with diarrhoea. Aust. Vet. J. 2011, 89, 167-173. [CrossRef]

5. Randhawa, S.S.; Randhawa, S.S.; Zahid, U.N.; Singla, L.D.; Juyal, P.D. Drug combination therapy in control of cryptosporidiosis in Ludhiana district of Punjab. J. Parasit. Dis. 2012, 36, 269-272. [CrossRef]

6. Niine, T.; Dorbek-Kolin, E.; Lassen, B.; Orro, T. Cryptosporidium outbreak in calves on a large dairy farm: Effect of treatment and the association with the inflammatory response and short-term weight gain. Res. Vet. Sci. 2018, 117, 200-208. [CrossRef]

7. Brar, A.P.S.; Sood, N.K.; Kaur, P.; Singla, L.D.; Sandhu, B.S.; Gupta, K.; Narang, D.; Singh, C.K.; Chandra, M. Periurban outbreaks of bovine calf scours in Northern India caused by Cryptosporidium in association with other enteropathogens. Epidemiol. Infect. 2017, 145, 2717-2726. [CrossRef]

8. Li, N.; Wang, R.; Cai, M.; Jiang, W.; Feng, Y.; Xiao, L. Outbreak of cryptosporidiosis due to Cryptosporidium parvum subtype IIdA19G1 in neonatal calves on a dairy farm in China. Int. J. Parasitol. 2019, 49, 569-577. [CrossRef]

9. Jacobson, C.; Al-Habsi, K.; Ryan, U.; Williams, A.; Anderson, F.; Yang, R.; Abraham, S.; Miller, D. Cryptosporidium infection is associated with reduced growth and diarrhoea in goats beyond weaning. Vet. Parasitol. 2018, 260, 30-37. [CrossRef] 
10. Shaw, H.J.; Innes, E.A.; Morrison, L.J.; Katzer, F.; Wells, B. Long-term production effects of clinical cryptosporidiosis in neonatal calves. Int. J. Parasitol. 2020, 50, 371-376. [CrossRef]

11. Khalil, I.A.; Troeger, C.; Rao, P.C.; Blacker, B.F.; Brown, A.; Brewer, T.G.; Colombara, D.V.; De Hostos, E.L.; Engmann, C.; Guerrant, R.L.; et al. Morbidity, mortality, and long-term consequences associated with diarrhoea from Cryptosporidium infection in children younger than 5 years: A meta-analyses study. Lancet Glob. Health 2018, 6, e758-e768. [CrossRef]

12. Steiner, K.L.; Ahmed, S.; Gilchrist, C.A.; Burkey, C.; Cook, H.; Ma, J.Z.; Korpe, P.S.; Ahmed, E.; Alam, M.; Kabir, M.; et al. Species of Cryptosporidia Causing Subclinical Infection Associated with Growth Faltering in Rural and Urban Bangladesh: A Birth Cohort Study. Clin. Infect. Dis. 2018, 67, 1347-1355. [CrossRef]

13. Feng, Y. Cryptosporidium in wild placental mammals. Exp. Parasitol. 2010, 124, 128-137. [CrossRef]

14. Feng, Y.; Ryan, U.M.; Xiao, L. Genetic Diversity and Population Structure of Cryptosporidium. Trends Parasitol. 2018, 34, 997-1011. [CrossRef]

15. Feng, Y.; Xiao, L. Molecular Epidemiology of Cryptosporidiosis in China. Front. Microbiol. 2017, 8, 1701. [CrossRef]

16. Feng, Y.; Alderisio, K.A.; Yang, W.; Blancero, L.A.; Kuhne, W.G.; Nadareski, C.A.; Reid, M.; Xiao, L. Cryptosporidium genotypes in wildlife from a new york watershed. Appl. Environ. Microbiol. 2007, 73, 6475-6483. [CrossRef]

17. Ziegler, P.E.; Wade, S.E.; Schaaf, S.L.; Stern, D.A.; Nadareski, C.A.; Mohammed, H.O. Prevalence of Cryptosporidium species in wildlife populations within a watershed landscape in southeastern New York State. Vet. Parasitol. 2007, 147, 176-184. [CrossRef]

18. Xiao, L.; Sulaiman, I.M.; Ryan, U.M.; Zhou, L.; Atwill, E.R.; Tischler, M.L.; Zhang, X.; Fayer, R.; Lal, A.A. Host adaptation and host-parasite co-evolution in Cryptosporidium: Implications for taxonomy and public health. Int. J. Parasitol. 2002, 32, 1773-1785. [CrossRef]

19. Zhang, W.; Shen, Y.; Wang, R.; Liu, A.; Ling, H.; Li, Y.; Cao, J.; Zhang, X.; Shu, J.; Zhang, L. Cryptosporidium cuniculus and Giardia duodenalis in rabbits: Genetic diversity and possible zoonotic transmission. PLoS ONE 2012, 7, e31262. [CrossRef]

20. Deng, L.; Chai, Y.; Luo, R.; Yang, L.; Yao, J.; Zhong, Z.; Wang, W.; Xiang, L.; Fu, H.; Liu, H.; et al. Occurrence and genetic characteristics of Cryptosporidium spp. and Enterocytozoon bieneusi in pet red squirrels (Sciurus vulgaris) in China. Sci. Rep. 2020, 10, 1026. [CrossRef]

21. Li, X.; Pereira, M.; Larsen, R.; Xiao, C.; Phillips, R.; Striby, K.; McCowan, B.; Atwill, E.R. Cryptosporidium rubeyi n. sp. (Apicomplexa: Cryptosporidiidae) in multiple Spermophilus ground squirrel species. Int. J. Parasitol. Parasites Wildl. 2015, 4, 343-350. [CrossRef]

22. Prediger, J.; Horčičková, M.; Hofmannová, L.; Sak, B.; Ferrari, N.; Mazzamuto, M.V.; Romeo, C.; Wauters, L.A.; McEvoy, J.; Kváč, M. Native and introduced squirrels in Italy host different Cryptosporidium spp. Eur. J. Protistol. 2017, 61, 64-75. [CrossRef]

23. Stenger, B.L.S.; Clark, M.E.; Kváč, M.; Khan, E.; Giddings, C.W.; Prediger, J.; McEvoy, J.M. North American tree squirrels and ground squirrels with overlapping ranges host different Cryptosporidium species and genotypes. Infect. Genet. Evol. 2015, 36, 287-293. [CrossRef]

24. Li, F.; Zhang, Z.; Hu, S.; Zhao, W.; Zhao, J.; Kváč, M.; Guo, Y.; Li, N.; Feng, Y.; Xiao, L. Common occurrence of divergent Cryptosporidium species and Cryptosporidium parvum subtypes in farmed bamboo rats (Rhizomys sinensis). Parasites Vectors 2020, 13, 149. [CrossRef]

25. Wei, Z.; Liu, Q.; Zhao, W.; Jiang, X.; Zhang, Y.; Zhao, A.; Jing, B.; Lu, G.; Qi, M. Prevalence and diversity of Cryptosporidium spp. in bamboo rats (Rhizomys sinensis) in South Central China. Int. J. Parasitol. Parasites Wildl. 2019, 9, 312-316. [CrossRef]

26. Lv, C.; Zhang, L.; Wang, R.; Jian, F.; Zhang, S.; Ning, C.; Wang, H.; Feng, C.; Wang, X.; Ren, X.; et al. Cryptosporidium spp. in wild, laboratory, and pet rodents in China: Prevalence and molecular characterization. Appl. Environ. Microbiol. 2009, 75, 7692-7699. [CrossRef]

27. Liu, X.; Zhou, X.; Zhong, Z.; Zuo, Z.; Shi, J.; Wang, Y.; Qing, B.; Peng, G. Occurrence of novel and rare subtype families of Cryptosporidium in bamboo rats (Rhizomys sinensis) in China. Vet. Parasitol. 2015, 207, 144-148. [CrossRef]

28. Li, N.; Xiao, L.; Alderisio, K.; Elwin, K.; Cebelinski, E.; Chalmers, R.; Santin, M.; Fayer, R.; Kvac, M.; Ryan, U.; et al. Subtyping Cryptosporidium ubiquitum, a zoonotic pathogen emerging in humans. Emerg. Infect. Dis. 2014, 20, 217-224. [CrossRef] 
29. Kváč, M.; Vlnatá, G.; Ježková, J.; Horčičková, M.; Konečný, R.; Hlásková, L.; McEvoy, J.; Sak, B. Cryptosporidium occultus sp. n. (Apicomplexa: Cryptosporidiidae) in rats. Eur. J. Protistol. 2018, 63, 96-104. [CrossRef]

30. Ng-Hublin, J.S.; Singleton, G.R.; Ryan, U. Molecular characterization of Cryptosporidium spp. from wild rats and mice from rural communities in the Philippines. Infect. Genet. Evol. 2013, 16, 5-12. [CrossRef]

31. Zhao, W.; Zhou, H.; Huang, Y.; Xu, L.; Rao, L.; Wang, S.; Wang, W.; Yi, Y.; Zhou, X.; Wu, Y.; et al. Cryptosporidium spp. in wild rats (Rattus spp.) from the Hainan Province, China: Molecular detection, species/genotype identification and implications for public health. Int. J. Parasitol. Parasites Wildl. 2019, 9, 317-321. [CrossRef]

32. Xiao, L.; Feng, Y. Molecular epidemiologic tools for waterborne pathogens Cryptosporidium spp. and Giardia duodenalis. Food Waterborne Parasitol. 2017, 8, 14-32. [CrossRef]

33. Chen, L.; Hu, S.; Jiang, W.; Zhao, J.; Li, N.; Guo, Y.; Liao, C.; Han, Q.; Feng, Y.; Xiao, L. Cryptosporidium parvum and Cryptosporidium hominis subtypes in crab-eating macaques. Parasites Vectors 2019, 12, 350. [CrossRef]

34. Insulander, M.; Silverlås, C.; Lebbad, M.; Karlsson, L.; Mattsson, J.G.; Svenungsson, B. Molecular epidemiology and clinical manifestations of human cryptosporidiosis in Sweden. Epidemiol. Infect. 2013, 141, 1009-1020. [CrossRef]

35. Garcia, R.J.; Pita, A.B.; Velathanthiri, N.; French, N.P.; Hayman, D.T.S. Species and genotypes causing human cryptosporidiosis in New Zealand. Parasitol. Res. 2020, 119, 2317-2326. [CrossRef]

36. Sannella, A.R.; Suputtamongkol, Y.; Wongsawat, E.; Cacciò, S.M. A retrospective molecular study of Cryptosporidium species and genotypes in HIV-infected patients from Thailand. Parasites Vectors 2019, $12,91$. [CrossRef]

37. Fayer, R.; Santin, M.; Trout, J.M. Prevalence of Cryptosporidium species and genotypes in mature dairy cattle on farms in eastern United States compared with younger cattle from the same locations. Vet. Parasitol. 2007, 145, 260-266. [CrossRef]

38. Santín, M.; Trout, J.M.; Fayer, R. A longitudinal study of cryptosporidiosis in dairy cattle from birth to 2 years of age. Vet. Parasitol. 2008, 155, 15-23. [CrossRef]

39. Mueller-Doblies, D.; Giles, M.; Elwin, K.; Smith, R.P.; Clifton-Hadley, F.A.; Chalmers, R.M. Distribution of Cryptosporidium species in sheep in the UK. Vet. Parasitol. 2008, 154, 214-219. [CrossRef]

40. Geurden, T.; Thomas, P.; Casaert, S.; Vercruysse, J.; Claerebout, E. Prevalence and molecular characterisation of Cryptosporidium and Giardia in lambs and goat kids in Belgium. Vet. Parasitol. 2008, 155, 142-145. [CrossRef]

41. Jiang, J.; Alderisio, K.A.; Singh, A.; Xiao, L. Development of procedures for direct extraction of Cryptosporidium DNA from water concentrates and for relief of PCR inhibitors. Appl. Environ. Microbiol. 2005, 71, 1135-1141. [CrossRef]

42. Xiao, L.; Bern, C.; Limor, J.; Sulaiman, I.; Roberts, J.; Checkley, W.; Cabrera, L.; Gilman, R.H.; Lal, A.A. Identification of 5 types of Cryptosporidium parasites in children in Lima, Peru. J. Infect. Dis. 2001, 183, $492-497$. [CrossRef]

43. Alves, M.; Xiao, L.; Sulaiman, I.; Lal, A.A.; Matos, O.; Antunes, F. Subgenotype analysis of Cryptosporidium isolates from humans, cattle, and zoo ruminants in Portugal. J. Clin. Microbiol. 2003, 41, 2744-2747. [CrossRef]

44. Sulaiman, I.M.; Lal, A.A.; Xiao, L. Molecular phylogeny and evolutionary relationships of Cryptosporidium parasites at the actin locus. J. Parasitol. 2002, 88, 388-394. [CrossRef]

45. Sulaiman, I.M.; Morgan, U.M.; Thompson, R.C.; Lal, A.A.; Xiao, L. Phylogenetic Relationships of Cryptosporidium Parasites Based on the 70-Kilodalton Heat Shock Protein (HSP70) Gene. Appl. Environ. Microbiol. 2000, 66, 2385-2391. [CrossRef]

46. Li, N.; Neumann, N.F.; Ruecker, N.; Alderisio, K.A.; Sturbaum, G.D.; Villegas, E.N.; Chalmers, R.; Monis, P.; Feng, Y.; Xiao, L. Development and Evaluation of Three Real-Time PCR Assays for Genotyping and Source Tracking Cryptosporidium spp. in Water. Appl. Environ. Microbiol. 2015, 81, 5845-5854. [CrossRef]

Publisher's Note: MDPI stays neutral with regard to jurisdictional claims in published maps and institutional affiliations. 